\title{
Gunshot Wound to the Head: Surgical Management and Cases Report in a Tertiary Care Center in Florencia, Colombia
}

\author{
Alejandro Rojas-Marroquín \\ Endovascular Neurosurgeon, Universidad Nacional Autónoma de México, México DF, México \\ Email: alejorojasm@gmail.com \\ Received 18 April 2015; accepted 30 June 2015; published 3 July 2015 \\ Copyright (C) 2015 by author and Scientific Research Publishing Inc. \\ This work is licensed under the Creative Commons Attribution International License (CC BY). \\ http://creativecommons.org/licenses/by/4.0/ \\ (c) () Open Access
}

\begin{abstract}
The purpose of this research is to report 10 cases treated in a tertiary care center in the Florencia town in Colombia. The time frame to this intervention was from $1^{\text {st }}$ June 2011 to $30^{\text {th }}$ June 2012. The idea was to establish the type, age group, Matson's classification schemes and mortality of the gunshot wound to the head in order to describe the neurological functional prognosis of these patients, made by The Modified Rankin scale (mRS) to 12 months postoperative.
\end{abstract}

\section{Keywords}

Gunshot, Head, Surgical Management, Modified Rankin Scale

\section{Introduction}

The trauma is the first cause of death in Colombia, around $50 \%$ of deaths are related to the traumatic brain injury. In Colombia, 76.67\% of murders were caused by gunshot [1]. In USA, the total cost due to treatment of gunshot wounds to the head is 16 billion dollars per year. In addition, 30\% of patients with gunshot wounds to the head arrive alive to the emergency room only [2] [3], its annual incidence is of 2.4/100,000 or 6000 murders per year [4] [5]. The deaths related to the gunshot are the second cause of death in the USA because of trauma, 58\% of which are murders and $57 \%$ suicides [6] [7].

\section{Cases Report}

A total of 10 patients were operated. They entered to the emergency room a cause their gunshot wounds of the head, they were 8 men and 2 women, the age range was between 19 and 65 years, the media age was 33.7 years 
old. At the time of admission, they had less than 8 in the Glasgow Coma Scale, the brain CT Scan (unenhanced) was realized to each one (Figure 1(a)), the Matson's scale was document and I continued with the surgical management. About each case, in general terms, with the bleeding control and the cerebral decompression, it was necessary a contaminated, macerated or ischemic tissue debridement (Figures 1(b)-(c)), the removal of bone and metal fragments, the profuse wash in the surgical bed, hermetically close of the dura matter and finally, the closure of the scalp; it was recommended in these cases [8] [9] (Figures 2(a)-(c)).

In our research $80 \%$ were male patients and $20 \%$ female patients, the media age was 33.7 years old. All the patients (100\%) were registred in the emergency room with less 8 in the Glasgow Coma Scale (Figure 3).

In this way, a patient's survival of $70 \%$ was register and $30 \%$ of death rate. These deaths were in the first 72 hours at ICU (intensive care unit) a cause the own complications of the gravity of the gunshot wounds of the head. At admission $60 \%$ of the patients had III B, $20 \%$ IV D, 10\% III C and IV B in the Matson's classification schemes respectively (Figure 4).

The Modified Rankin scale (mRS) at 12 months post surgery was: 30\% mRS 4, 20\% mRS 3, 10\% mRS 2 and $10 \%$ mRS 5 (Figure 5).

\section{Discussion}

The wound by gunshot are a serious public health problem that affects Colombia, with very high economic costs as well as severe neurological disabilities afflicting predominantly young people. This situation demonstrates the intolerance in our society and insecurity that afflicts us too.

\section{Conclusion}

It was confirmed that the Glasgow Coma Scale, at admission, is the most important variable that defines the

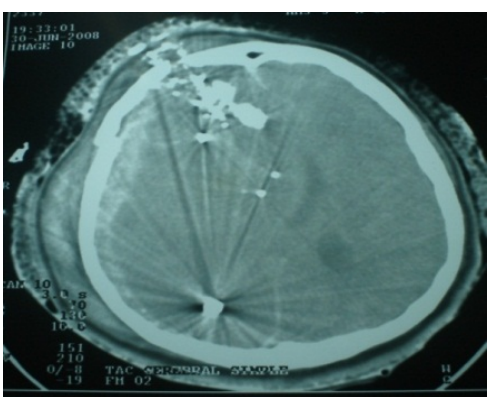

(a)

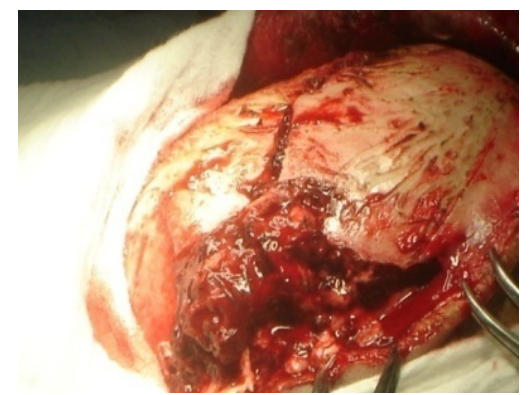

(b)

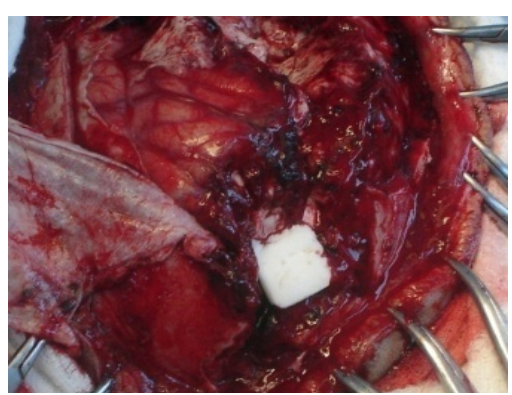

(c)

Figure 1. (a) Brain CT Scan (unenhanced): numerous metal shards from the right frontal region to the right occipital region, subdural hematoma and brain edema; (b) Comminuted fracture of right cranium, dural tear, brain laceration and output mecerated brain; (c) Post surgical subtotal right frontal lobectomy (lobotomy), drainage of intracranial hemorrhage and surgical debridement.

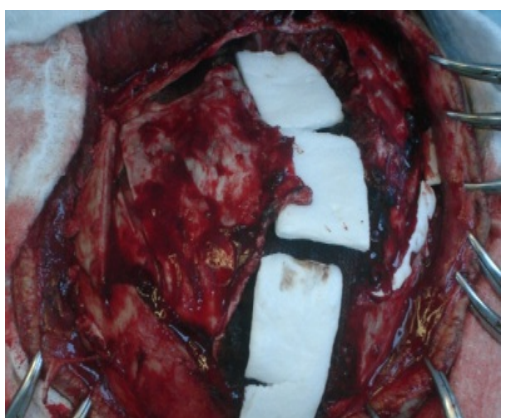

(a)

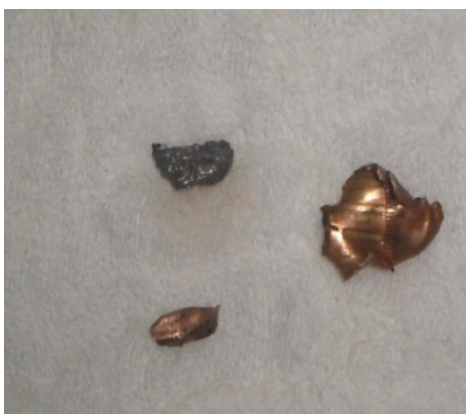

(b)

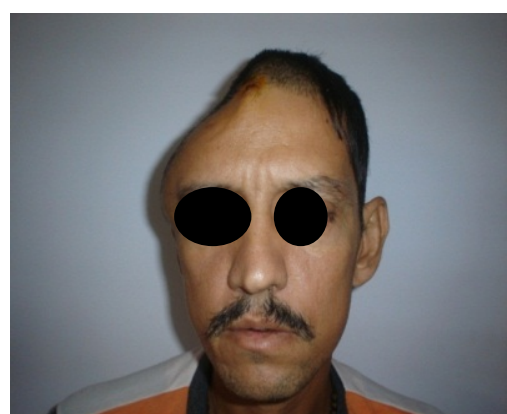

(c)

Figure 2. (a) Placement homeostatic material on the surgical bed; (b) Projectile fragments of gunshot; (c) Anterior view of the patient to 12 months post surgery. 
survival and degree of functional disability of the patient, thus, the lower is the GCS at admission, the highest income will be modified Rankin scale and higher mortality. These results coincide with reports of world literature. The results of this study are synthesized in the Annex 1 (Figure 6).

\section{GLASGOW COMA SCALE AT ADMISSION}

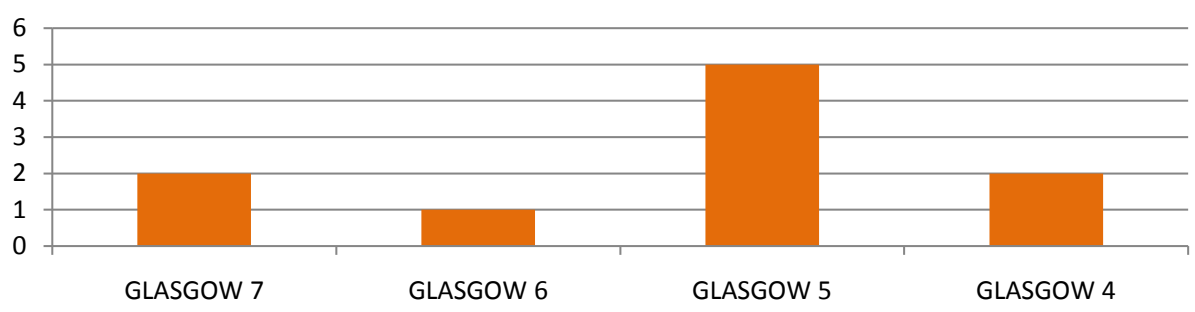

Figure 3. Glasgow Coma Scale (GCS) at admission. 50\% of patients were admitted with GCS: 5, 20\% with GCS: 4 and 7 respectively, and 10\% with GCS: 6.

\section{MATSON SCALE}

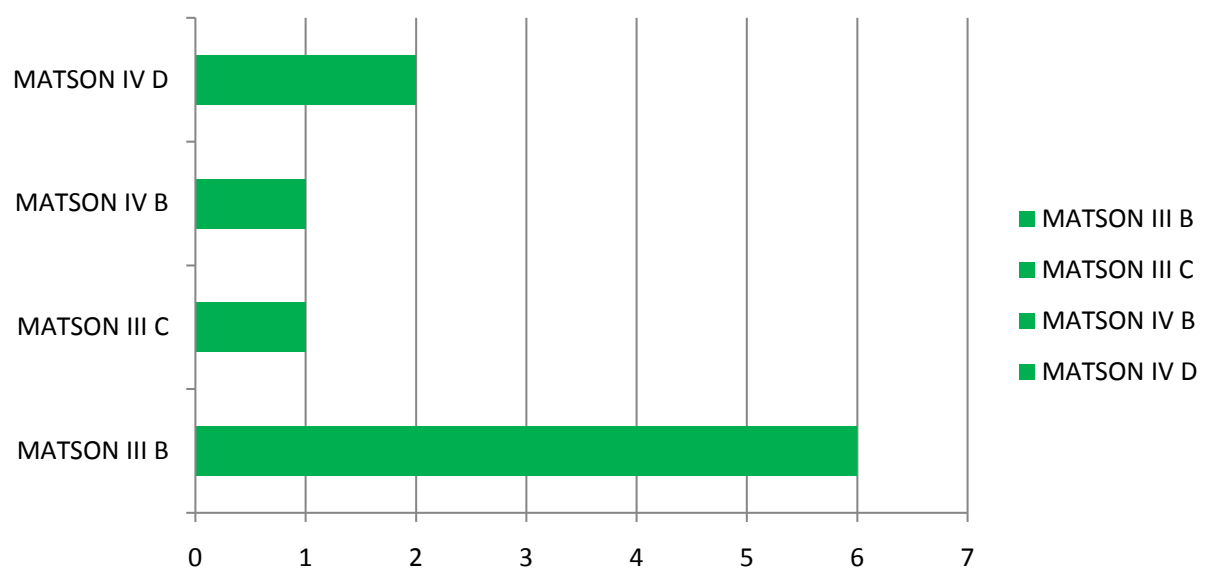

Figure 4. Matson's scale. $60 \%$ of the patients rated IIIB, 20\% IV D, $10 \%$ III C and IV B respectively.

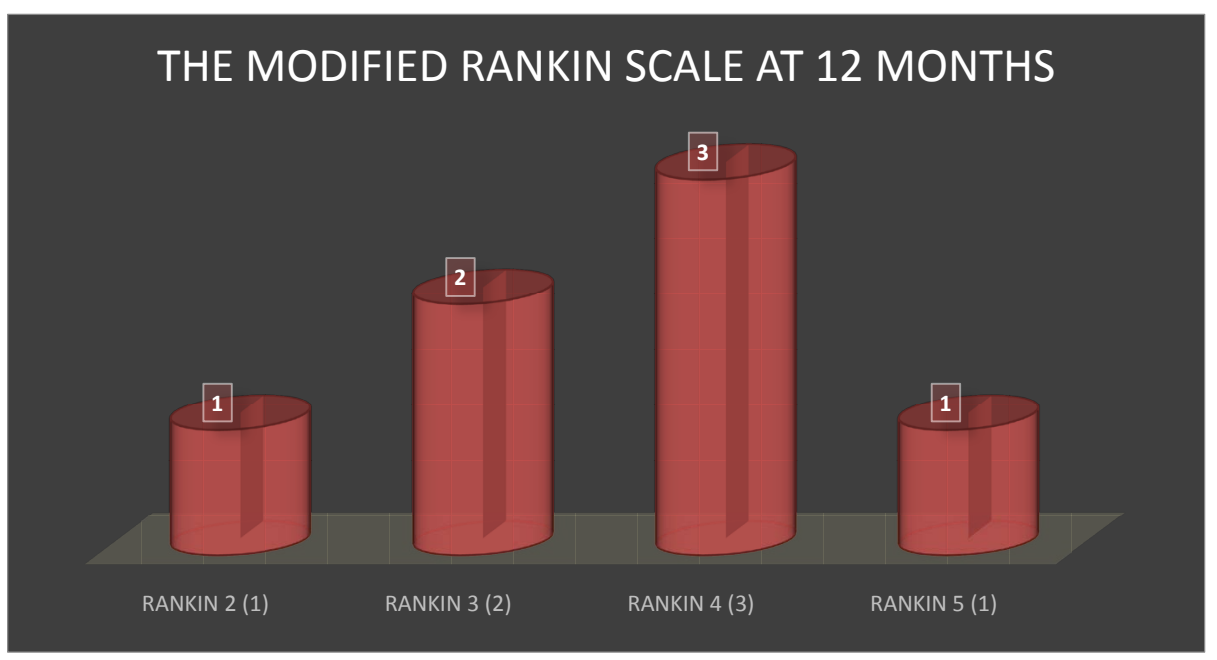

Figure 5. The Modified Rankin scale (mRS) at 12 months. The mRS at 12 months post surgery was: $10 \%$ mRS: $2,20 \%$ mRS: $3,30 \%$ mRS: 4 and $10 \%$ mRS: 5 . 


\begin{tabular}{|c|c|c|c|c|c|c|}
\hline & & $\begin{array}{r}\text { SUN } \\
\text { UNSHC }\end{array}$ & $\begin{array}{c}\text { ANNEX } 1 . \\
\text { ARY OF FIN } \\
\text { WOUND TO }\end{array}$ & $\begin{array}{l}\text { DINGS } \\
\text { THE HEAD }\end{array}$ & & \\
\hline PATIENT & SEX & AGE & $\begin{array}{c}\text { GLASGOW } \\
\text { COMA } \\
\text { SCALE }\end{array}$ & $\begin{array}{c}\text { MATSON } \\
\text { SCALE }\end{array}$ & ALIVE & $\begin{array}{c}\text { mRS } \\
\text { AT 12 } \\
\text { MONTHS }\end{array}$ \\
\hline 1 & $M$ & 19 & 5 & III B & YES & 4 \\
\hline 2 & $\mathrm{M}$ & 30 & 4 & III C & NOT & ..................... \\
\hline 3 & $M$ & 29 & 5 & III B & YES & 4 \\
\hline 4 & $\mathrm{~F}$ & 26 & 4 & IV B & NOT & ………....... \\
\hline 5 & $M$ & 25 & 5 & IV D & YES & 5 \\
\hline 6 & $\mathrm{M}$ & 36 & 7 & III B & YES & 2 \\
\hline 7 & $\mathrm{~F}$ & 65 & 5 & III B & YES & 4 \\
\hline 8 & $\mathrm{M}$ & 31 & 7 & III B & YES & 3 \\
\hline 9 & $\mathrm{M}$ & 33 & 5 & IV D & NOT & ………....... \\
\hline 10 & $\mathrm{M}$ & 43 & 6 & III B & YES & 3 \\
\hline
\end{tabular}

Figure 6. Annex 1. Summary of findings gunshot wound to the head.

\section{Disclosure}

The author declares that he has no conflict of interest.

\section{References}

[1] National Institute of Legal Medicine and Forensic Sciences of Colombia (2013) Grupo Centro de Referencia Nacional sobre Violencia/Sistema de Información Red de Desaparecidos y Cadáveres/Sistema de Información Nacional de Estadísticas Indirectas. Forensis.

[2] Trask, T.W. and Narayan, R.K. (1996) Civilian Penetrating Head Injury. In: Narayan, R.K., Wilberger, J.E. and Povlishock, J.T., Eds., Neurotrauma, McGraw-Hill, New York, 869-887.

[3] James, E., Geoffrey, S.F.L. and Rengachary, S.S. (2005) Gunshot of the Head. In: Principles of Neurosurgery, 2nd Edition, Elsevier, Mosby, 319-327.

[4] Kaufman, H.H., Schwab, K. and Salazar, A.M. (1991) A National Survey of Neurosurgical Care of Penetrating Head Injury. Surgical Neurology, 36, 370-377. http://dx.doi.org/10.1016/0090-3019(91)90026-6

[5] Rosenberg, W.S. and Harsh IV, G.R. (1996) Penetrating Wounds of the Head. In: Wilkens. R.H. and Rengachary, S.S., Eds., Neurosurgery, McGraw-Hill, New York, 2813-2820.

[6] Knightly, J.J. and Pulliam, M.W. (1996) Military Head Injury. In: Narayan, R.K., Wilberger, J.E. and Povlishock, J.T., Eds., Neurotrauma, McGraw-Hill, New York, 891-902.

[7] Grahm, T.W., Williams, F.C., Harrington, T. and Spetzler, R.F. (1990) Civilian Gunshot Wounds to the Head: A Prospective Study. Neurosurgery, 27, 696-700. http://dx.doi.org/10.1227/00006123-199011000-00005

[8] Brain Trauma Foundation (2007) Guidelines for the Management of Severe Traumatic Brain Injury. Journal of Neurotrauma, 24, i-vi. http://dx.doi.org/10.1089/neu.2007.9999

[9] Aarabi, B., Alden, T.D., Chestnut, R.M., et al. (2001) Management and Prognosis of Penetrating Brain Injury. Journal of Trauma-Injury Infection \& Critical Care, 51, S1. http://dx.doi.org/10.1097/00005373-200108001-00001 